\title{
The key to digitization success: making the school librarian a true pedagogical partner
}

\author{
Liselott Drejstam \\ Hjulsbroskolan \\ Bokhagsvägen 5 \\ 58181 Linköping \\ Sweden \\ liselott.drejstam@linkoping.se \\ Martina Lundström \\ Linköpings kommun \\ Apotekaregatan $13 \mathrm{c}$ \\ 58181 Linköping \\ martina.lundstrom@linkoping.se
}

\begin{abstract}
In Linköping there is an ongoing investment to digitize schools. This means that schools are equipped with projectors, computers, iPads and Apple TV for wireless transmission to the whiteboard. The investment will hopefully lead to a pedagogical improvement in teaching and higher achievement among pupils. Many teachers need more knowledge to give pupils good opportunities for active learning with digital tools. In order to meet teachers' needs for skill development, Linköping has together technology investments also made a major investment in school libraries with employed librarians, so called focus libraries. All schools with focus libraries have educated school librarians with full-time mission integrated in the school, working together with teachers. The librarian devotes most of her time in the classroom with the teachers to plan, implement and evaluate the area of work and assess the pupils' efforts. In this cooperation digital tools is often used.
\end{abstract}

Keywords: school libraries, school librarians, digitization, media and information literacy, digital technology

\section{Introduction}


In Linköping, pupils and teachers use digital technology in everyday life and in most classes. Since two years we have wireless networks in all classrooms, in all preschools and schools. All pupils have access to computers, iPads and Apple TV for wireless transmission to the whiteboard. This is a technology investment and we are aiming for pedagogical improvement in teaching. We strive for high results and offer all the pupils education based on three key words - Learning, Equal Opportunities and Engagement. However, it takes more than technology to provide pupils with high quality education. Many teachers need more knowledge to give pupils good opportunities for active learning with digital tools. In order to meet teachers' needs for skill development, Linköping has besides technology investments also made a major investment in school libraries with employed librarians, we call them focus libraries. All schools with focus libraries have educated school librarians with full-time mission integrated in the school, working together with teachers. The librarians strive to promote reading and to help to develop information literacy among pupils and their teachers. School librarians work together with first teachers and the head teachers to ensure that digital initiatives are implemented and used to enhance learning in every school. In this paper we will present a background for the digitization of schools at a national level in Sweden. We will also give successful examples of our work and how Linköping has chosen to digitize the schools and how teachers and pupils use digital technology in the classroom. The examples come from Hjulsbroskolan, a school with a focus library and a full time school librarian. In 2015, Hjulsbroskolan received the award School Library of the Year.

\section{Digitization of schools in Sweden}

In 2011 a new curriculum, Lgr11, was implemented. The curriculum consists of fundamental values and tasks for the school, overall goals and guidelines and syllabuses. Pupils in elementary school study the following topics: art, English, home and consumer studies physical education and health, mathematics, modern languages, mother tongue tuitions, music, biology, physics, chemistry, geography, history, religious studies, civics, crafts, Swedish, Swedish as a second language , sign language for the hearing and technology. The curriculum states as follows: "the school is responsible for ensuring that each pupil on completing compulsory school can use modern technology as a tool in the search for knowledge, communication, creativity and learning" (Lgr11, 2011, p. 15).

There is also specific guidelines for the headmaster: 
As both pedagogical leader and head of the teaching and non-teaching staff in the school, the head teacher has overall responsibility for ensuring that school activities as a whole are focused on the national goals. The head teacher is also responsible for following up and evaluating school results in relation to the national goals and the knowledge requirements. The head teacher is responsible for the results of the school and within given constraints, has special responsibility for ensuring that: the working environment in the school is organized such that pupils have access to guidance, teaching material of high quality, as well as other assistance in order to be able to independently search for and acquire knowledge through such means as libraries, computers, and other learning aids (Lgr11, 2011, p. 20).

Sweden is in10th place in the world among countries with the most Internet users (Internet Live Stats, 2016). 93\% of the population, have Internet access at home, and IT is used daily in all areas such as health care, trade, infrastructure and schools. In the older generation, among those born in the 20 s and 30 s, fewer people use the Internet. Even younger children in Sweden are using Internet highly. Most families have access to both PC, tablet and smartphone and small children surf the Internet regularly. $67 \%$ of two-year-olds are using the Internet each week (Internetstiftelsen i Sverige).

Although the common use of IT in Swedish homes, IT is used to a lesser degree in the teaching and the use is unevenly distributed. In year 4 , it is only $50 \%$ who use the Internet every week (Internetstiftelsen i Sverige). Some municipalities have had computers to all pupils in more than 10 years while there are still municipalities that have not yet made the necessary investments needed for a modern way of working at school. Even within municipalities and within individual schools there is a big difference in how the technology is used for learning.

The unequal use of IT in schools has been criticized by politicians for a long time and that a national strategy for IT in Swedish schools is desirable. In autumn 2015 the National Agency for Education received a government commission to develop a proposal for what should be included in a national IT strategy. The national strategy for IT will be addressed to pupils and teachers in preschool, school, recreation center and secondary school. The national strategy for IT consists of a vision for the desired direction over the coming years, greater focus on teacher training, elements of programming and a digitization of the national tests. 
The National Agency for Education's proposal is called "Vision 2022" and will be valid 2017-2022 provided that the government in 2016 will take necessary decisions in order to realize the vision. The plan is long term as it takes time for local authorities to make necessary investments in infrastructure. National Agency for Education believes that it is reasonable to believe that all pupils and teachers can achieve the following vision for 2022 :

- All children and pupils have developed adequate digital literacy.

- The school system is characterized by digitization opportunities that are utilized so that the digital tools and resources will help to improve results and make activities in school more efficient.

The vision to develop "adequate digital literacy" is deliberately vague written. It is not possible with a clarification of what is meant by "adequate" because the development of school digitizing is rapid. What is valid today may not have the same effect tomorrow. We do not know what tools we will be using in five years and the school must be prepared for rapid changes.

The second vision about digitization opportunities to improve and make more effective operations contains several different parts. This involves both making effective workflows for teachers with the support of digital technology and the development of teaching in the classroom. In many classrooms digital technology is used in teaching primarily for word processing and consumption of software, apps and films. The vision contains a desire for pupils to be co-creator and use technology rather than being producers.

Within certain subjects digitization opportunities is used to a greater degree than others. In mathematics, the use rate is low but the new IT strategy entails that pupils will use their devices to a greater degree when programming becomes part of the subject.

Besides including programming in mathematics it is also being included in technology. It will require efforts on skills, because many teachers in today's schools do not have the necessary skills to work with this in their subject. The community asks for programming skills and anyone who knows programming will easily be able to find employment in their professional future. 
The national strategy for IT also includes benchmarks for how technology dense schools should be. Within three years all pupils should have access to wireless networks and a device of their own to be used in teaching.

Results in Swedish schools has dropped for several years (OECD 2015), for example in literacy, mathematics and science. The National Agency for Education has made a major investment in skills development through both mathematics and reading. Swedish research on the digitization of school shows that there are potential risks in teaching (Fleischer, 2013). In classrooms with high technology density where teachers do not change their teaching, the pupils risk losing even more in performance. It depends largely on that the pupils are left alone in their learning.

However, teachers who use technology to promote teaching can be very successful and results from technology dense schools in Sollentuna, Sweden, shows that pupils in year 3 have succeeded very well in the national tests in Swedish and mathematics (Genlott \& Grönlund, 2013).

In a big research project five success factors are identified as particularly important for a successful digitization of schools. These five concerns:

1. Teachers' digital literacy, i.e. their ability to constructively and effectively use information and other digital resources, and the school's ability to assess the quality and assimilate methods where the technology is used in the best possible way.

2. A local bank of shared educational resources known and regularly used by all.

3. A unified digital learning environment that integrates not only the school but also, where applicable, the municipality or district.

4. A financial system that leads to that computers are not used to replace the teacher but as a tool for them to improve their teaching.

5. Head teachers' ability to promote development in the right direction for a long time. (Grönlund, 2014)

While the national strategy for IT is adopted there will also be an investment to increase knowledge for teachers and headmasters through the National Agency for Educations IT investments. One of the investments are particularly addressed to the head teachers. Håkansson Lindqvist and Grönlund argues that the head teachers' ability to lead a technology dense school is crucial on how well teachers will succeed. (Håkansson Lindqvist, 2015 and Grönlund, 2014). In addition to the investment for 
head teachers the National Agency for Education also has several modules based on IT-skills for teachers. This involves Confident and critical use of Internet, Digital Tools for Learning, Leading and learning in technology dense classrooms and Digital tools for inclusion and special needs. Teachers will learn, test, and evaluate teaching together with other teachers, a systematic approach with the ability to produce good results (Timperley et al, 2007). Teachers need time for professional development of their teaching together with other teachers. Previous government investment in IT skills have been more individual and more software-based.

\section{Digitization in Linköping}

The municipality of Linköping, with 150000 inhabitants, has made a major effort to digitize all classrooms and all kindergartens. In all classrooms you can find interactive whiteboards with projectors and speakers. All pupils, including children in pre-school, have access to $\mathrm{iPad}$, and Apple TV is available to all projectors. Schools and kindergartens have access to good wireless network login via eduroam. To support the digitization of the classroom there are ICT educators in all schools, which educate and inspire colleagues in using digital tools in everyday teaching. In the effort to digitize the classroom, teachers have been given access to a platform, LMS, for teaching, digital encyclopedias and SkolArena to search, share and gather information.

Efforts to develop teaching with digital tools has been going on for several years. We have had a number of major development projects with the aim to find ways to integrate digital technology into daily teaching. The first pupils who got an iPad where those in special schools because we felt that these pupils benefit greatly by being able to communicate using digital tools. A goal has been to not see ICT as a special activity in education, but rather to integrate technology into daily teaching.

In Linköping there is a development center which is responsible to support and inspire teachers to develop their teaching with ICT as a tool. The aim of the development center is to challenge children and pupils learning for a higher goal achievement. When the school is digitized teachers need both technical and didactic professional development. Teachers in Linköping receive training in both areas but it is the didactic training that we focus most on. Teachers have had courses based on peer learning with a tutor, an approach with good opportunities to promote good teaching (Timperley et al, 2007). The focus on ICT development has taken place in three major areas, subject development, early reading and writing, and computational thinking. 
With peer learning in subject teachers' teams, teachers have developed teaching based on Black and Wiliams five key skills. The emphasis in these key competences are all about working formative and where we have found the digital tools to be especially meritorious. These five key skills are:

1. Clarifying, sharing, and understanding learning intentions and criteria for success.

2. Engineering effective classroom discussions and other learning tasks that elicit evidence of student understanding.

3. Provide feedback that moves learners forward.

4. Activating students as instructional resources for one another.

5. Activating students as the owners of their own learning (Black \& Wiliams, 2009).

Teachers who work with early reading and writing skills have had support for trying out new approaches and many teachers in Linköping today use the method "write to read." This method means that the pupil has access to TTS so that they can listen to what they have written. They start off by only using the keyboard and letters are not formed by hand until year 2. Pupils often work in pairs to discuss their texts. This means that pupils usually produces longer texts and the boys write more than they did before.

The municipality of Linköping, together with the University of Linköping have had a major focus on computational thinking in elementary school. The digital society means that teachers need to be familiar with new, partly, different, ways of working in school. The computational thinking is about to describe, analyze and solve problems using computers and we have used programming as a method to give pupils readiness to be digital producers. Even within the computational thinking, it is peer learning that has enabled the development of skills. The purpose of introducing computational thinking in education is to offer all pupils a challenging education where they are given the opportunity to develop skills such as problem solving and creativity. An education that enables them to understand the digital world and to develop skills to meet future job requirements.

\section{School libraries in Sweden}

The school library situation around Sweden varies a lot. Some municipalities stand out with their investment in school libraries, other municipalities have no plan at all for school libraries at all. Some municipalities (for example Lund, Växjö and 
Linköping) have realized that staffed school libraries is an important for the pupils' achievements.

The Education Act of 2011 states that "pupils in elementary school, school for pupils with intellectual disabilities, special school, Sami school, secondary school and upper secondary school for pupils with learning disabilities should have access to school libraries." (Skollag, 2010, 36§)

The Education of act does not focus on library staff at all. That leads to an uneven school library situation in Sweden. Many schools have a school library, but a few has a librarian. The National Library of Sweden stated in 2014 that a school library with at least 20 hour staffing should be considered a school library. Their survey found that more than half of Swedish pupils do not have access to a staffed school library. (Kungliga biblioteket, 2014)

The Swedish Schools Inspectorate works to ensure that pupils in Sweden are getting a good and equal education. They are looking at a certain criteria to decide if the school has a school library:

1. "Pupils have access to a school library in their own school unit's premises or at a reasonable distance from the school that makes it possible to continuously use the library as part of pupils' education in order to contribute to achieving the objectives of their education.

2. The library includes books, nonfiction and fiction, information technology and other media.

3. The library is adapted to the needs of the pupils in order to promote language development and stimulate reading." (Skolinspektionen, 2013)

\section{School libraries' role in the digitization process at a national level}

In the article Skolbibliotekens bidrag till skolans digitalisering (School library's contribution to the school's digitization) Stefan Pålsson states that "school libraries and school librarians are an important and invaluable resource when school is digitized." (Pålsson, 2016).

Head teachers who have chosen to invest in school libraries have also seen the benefits of using the school librarian as a resource in the process of digitization. One of these head teachers is Edward Jensinger, former head teacher of the Pauli Gymnasium in Malmö. He believes that "to kick start the development of the school 
so that it becomes digitally literate the head teacher must be raking the ring for teachers and other educational staff, such as school librarians who have a key position when school is digitized" (Grönlund, 2014, s. 102).

This is something Håkan Fleischer also has pointed out several times. He has done a lot of research on 1:1 investments and he is convinced that information retrieval and source criticism is one of the cornerstones of the 1:1 education. Librarians have a lot of education in these areas, which teachers often lack. The librarian has got an overview of the topics and resources and can be a helpful partner to the teachers (Fleischer, 2014).

Even in the ICT strategy for schools states that "a natural resource regarding digitization is the school library with a library trained staff. A strategic development of school libraries function in the work with media management and media critical work is of great importance. Librarians' skills need to be utilized especially when it comes to developing teachers' skills in information and source criticism (Skolverket, 2016).

In several sources you can find evidence on how important a school librarian is in our digital age. Hopefully this will lead to that more schools will make investments in staffed school libraries and make the school librarian a part of the digitization process.

\section{Focus libraries in Linköping}

In Linköping the municipality has chosen to make an investment in staffed school libraries. These are called focus libraries, to separate school libraries with trained school librarians from school libraries without school librarians. Right now there are 23 librarians in 27 schools. Schools may apply to have a focus library. Every year there are about four new focus libraries. The idea is that all school libraries in Linköping should be staffed in the future. When a school is granted a focus library they get a full-time librarian, additional funds for purchase of media and furniture. For two years the school receive money for this from the municipality. After two years, the school carries the costs gradually. This will free the money to invest in new focus libraries.

Focus libraries have three aims:

- Be an integrated part of school activities

- Work to promote reading

- Develop pupils' information literacy 
Each school with a focus library has developed an action plan for how these three goals should to be realized. The action plan should be aligned to the school's own conditions and needs. It is important that all teachers at the school are involved in establishing the plan to realize the goals of it.

\section{The role of focus libraries in the digitization process in Linköping}

The aims of the focus libraries are easy to integrate with the ongoing efforts to digitize schools in Linköping. In the Library plan for Linköping the school libraries mission in the digitization process is as follows:

In order to integrate the ITC technology as an integral part of the educational learning in preschool and school municipality of Linköping intends to:

- Continue the investment to integrate digital learning resources as a natural part of teaching.

- Develop digital communication between the school, pupils and guardians.

- Ensure that the ITC technology is available on the conditions of pedagogical work. With the libraries as an integrated part of school teaching exciting possibilities opens up in terms of the digital learning. Learning resources on the Internet and learning materials in digital form is a reality today and librarians' skills are essential for building strategies and for the use of digital tools and also for the information search process. (Linköpings kommuns biblioteksplan).

Further, the plan states the "with support from the school library, pupils learn to navigate in the information flow and learn how to be source critical. Pupils should obtain digital skills by learning to use modern technology for information retrieval, communication, creativity and learning" (Linköpings kommuns biblioteksplan).

Schools in Linköping has several systems to facilitate and encourage the use of digital tools. One of these systems is the SkolArena, which is a website where you can search for information in many different databases simultaneously, but also publish pupils' work. On SkolArena, you can find a variety of e-books written by pupils in primary schools. The school librarians are editors and have the 
responsibility to publish e-books on SkolArena. It opens up for collaboration between teachers and school librarians.

Another tool for publishing pupils' work is Linkopedia, Linköpings own educational wiki. Here you can publish pupils' factual texts.

Focus librarians also have some missions at municipal level, including participating in in-service training days to lecture on media and information literacy and useful apps. This is part of the digitization process in Linköping, to make sure that teachers know how to use digital tools wisely.

\section{Digitization and the school library in Hjulsbro School}

The school librarian at Hjulsbro school also has a role as ICT teacher. This has proved successful, not least because it has facilitated cooperation between teacher and librarian in terms of developing pupils' media and information literacy. The school librarian have supported the teachers in use of digital tools.

Below is an example of work where teachers and librarian have cooperated using digital tools / resources:

\section{Autumn talks}

Pupils wrote an autobiography which they recorded with the app GarageBand. We created a pod-radio show out of the recordings which one can be listened to on our blog Våra möten med böcker (http://våramötenmedböcker.se/).

\section{Description of a charachter}

By using the app Vintage people the pupils took a photo of themselves and inserted in any of the historical images in the app and wrote an ad to a friend who had disappeared. The ad was written in Pages on iPad.

\section{Classic books in a modern age}

Pupils read a variety of classic books (for example The call of the wild by Jack London, The Hunchback of Notre Dame by Victor Hugo and The phantom ship by Frederick Marryat) in groups of four. They searched for information about the book's author. The facts were presented in a collage made in Glogster on a computer or PicCollage on iPad.

\section{Conversations in literature using digital tools}


As an alternative to traditional conversations of literature we sometimes use

TodaysMeet to discuss the text. All pupils connect to page and write posts about the text we've read.

\section{Digital tools used on pupils' leisure time}

In cooperation with recreation centers, pupils have worked with a range of digital tools in various fields. They have worked with apps that practice coding, apps that stimulate storytelling and apps for filmmaking.

\section{Information retrieval / source criticism}

Media- and information literacy recur in all grades from preschool to year 6 , always connected to the an area of work matched with the core content in the curriculum.

The school librarian participate in the entire area of work, from planning to evaluation.

\section{Write to read}

The school librarian participate in the write-to-read classes to support pupils in their learning and writing skills. In this way, the school librarian is a part of the pupils' reading and writing skills from the start, which can help them to develop as readers.

Digital technology is used in a sensible and varied way at Hjulsbro School. The school librarian usually have the responsibility to teach pupils how to use the technology, while the teacher is responsible for the subject content.

\section{Results}

Efforts to digitize classrooms in Linköping and give pupils access to iPad to use in everyday teaching has meant that pupils largely use the Internet. In measurable statistics in digital systems, we see that the technology is used but how much it is used varies widely between schools. Quantitative results in terms of measurable changes in grades or national tests have not yet been demonstrated more than in some smaller parts (more on that below.) Qualitative results however show that many teachers are willing to change their teaching.

The three major investment in skills development, subject development, "write to read" and "computational thinking", has made its mark in various ways at school.

A majority of the teachers participated in subject development, which ran from 20112015 , and it is one of the investments that may have played a role in pupil learning in 
the classrooms of Linköping. The focus of the subject development has been formative assessment and during 2014-15 the participating teachers was provided with an iPad. The choice to focus on formative assessment has been based on a desire for increased impacts deriving from research on effective strategies in teaching, (Hattie 2008, Black \& William 2009). Over time, the municipality of Linköping have had good development on pupil outcomes. The results of pupils' grades in grade 9 have increased between year 2009-2015.

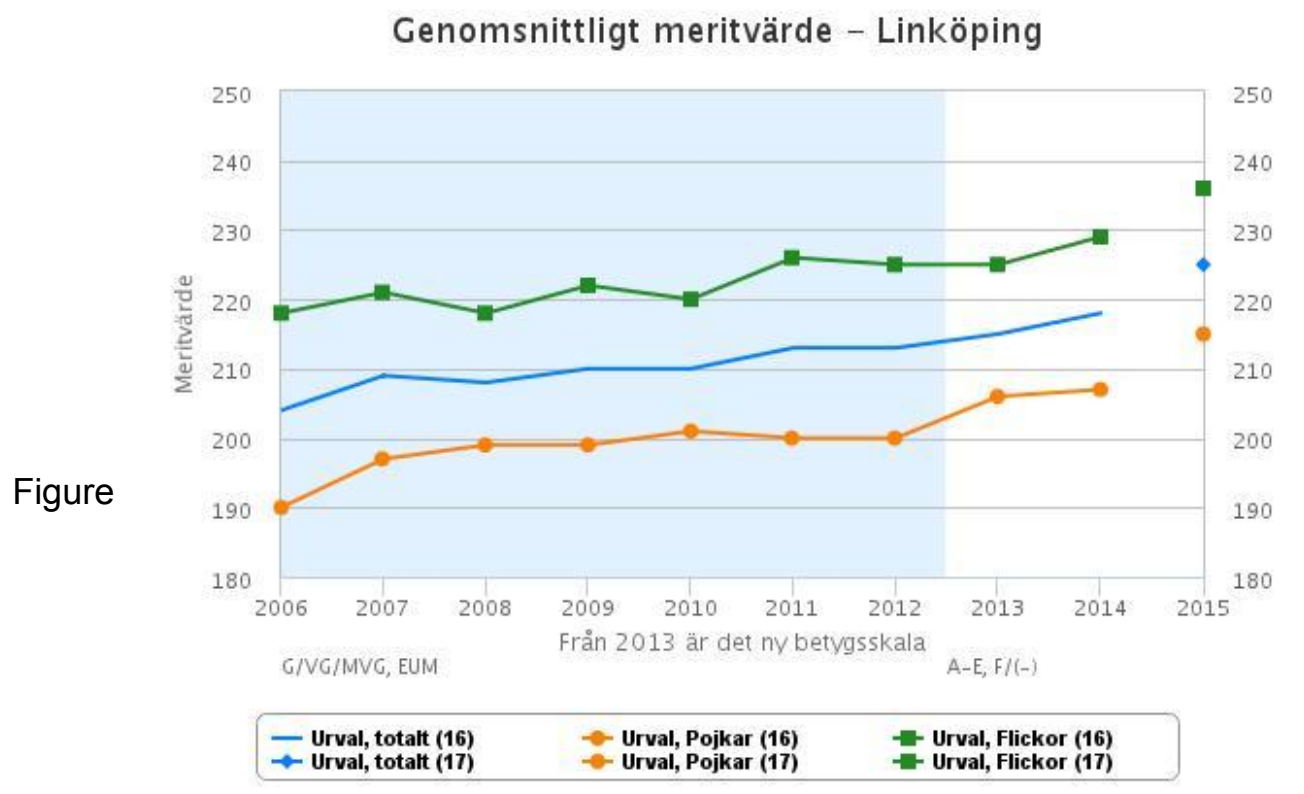

Average merit rating 2006-2015 
The focus on "write to read" has been going on for one year and it is not yet possible to see any results in young children's literacy development. What we can see is that the interest to participate in voluntary courses about the method have been great. Most of Linköping schools have had teachers who have participated in these courses and the results will be followed over time.

When it comes to the investment in the "computational thinking" it is so far only a small part of the teachers who have participated and it is still not possible to see the ways in which it contributes to higher achievement.

A survey made by Liselott Drejstam and Catrin Eriksson, former head of school libraries in Linköping, shows that pupils attending schools with a focus library reach higher results on questions about source of criticism in the national tests. Common to all the schools with high results is that the school librarian and the teacher have collaborated to develop pupils' source critical ability. The ability has been developed in work areas where pupils have been searching for and evaluating information, with support from the librarian and teacher. The pupils would not have reached that high achievement if the access to technology had been lacking (Drejstam \& Eriksson).

Within the national strategy for IT for Swedish schools there is a possibility of training in form of a national school development program. It can provide teachers and head teachers with better tools to work with success factors identified in the Swedish research on digital classroom (Grönlund 2014). In the municipality of Linköping, we look forward to further improve the digital literacy of teachers and increase the head teachers' ability to lead in the right direction to reach higher achievement. The school librarian is involved in this process.

\section{References}

Black, P. \& Wiliam, D. (2009). Developing the theory of formative assessment. Educational Assessment, Evaluation and Accountability, 21(1). Retrieved May 5, 2016, from

https://kclpure.kcl.ac.uk/portal/files/9119063/Black2009 Developing the theory of $\mathrm{f}$ ormative assessment.pdf

Curriculum for the compulsory school, preschool class and the recreation center 2011 (Lgr11). (2011). Stockholm: Skolverket. 
Drejstam, L. \& Eriksson, C. (n.d.). Källkritik i de nationella proven. Retrieved May 25, 2016, from

http://www.linkoping.se/Global/Skola\%20och\%20barnomsorg/F\%c3\%b6rvaltning/sko lutveckling/Enheten $\% 20 f \% c 3 \%$ b6r\%20metodst $\%$ c3\%b6d/K\%c3\%a4llkritik\%20i\%20n ationella\%20prov.pdf?epslanguage=sv

Fleischer, H. (2013). One student - one computer. The quality of and conditions for knowledge formation in the digitalised school. TMB Jönköping: Tabergs AB.

Fleischer, H. (2014). Skolbibliotekarier är alltjämt nyckelpersoner den datoriserade skolan. Retrieved May 20, 2016, from http://www.fleischer.se/skolbibliotekarier-aralltjamt-nyckelpersoner-i-en-till-en-projekt/\#.Vz4Mostf3IU

Genlott, A.A. \& Grönlund, Å. (2013). Improving literacy skills through learning reading by writing: The iWTR method presented and tested. Computers \& Education, 67. Retrieved May 5, 2016, from http://dx.doi.org/10.1016/j.compedu.2013.03.007

Grönlund, Å. (2014). Att förändra skolan med teknik: Bortom "en dator per elev". Örebro: Örebro universitet.

Hattie, J. (2008). Visible Learning: A Synthesis of Over 800 Meta-Analyses Relating to Achievement. Oxford: Routledge.

Håkansson Lindqvist, M. (2015). Conditions for Technology Enhanced Learning and Educational Change A case study of a 1:1 initiative. Umeå: Print and Media.

Internet Live Stats. (n.d.) Internet Users by Country. Retrieved May 5, 2016, from http://www.internetlivestats.com/internet-users-by-country/

Internetstiftelsen i Sverige. (n.d.) Svenskarna och internet: 2015 års undersökning av svenska folkets internetvanor. Retrieved May 5, 2016, from https://www.iis.se/docs/Svenskarna och internet 2015.pdf

Johnson, L., Adams Becker, S., \& Hall, C. (2015). 2015 NMC Technology Outlook for Scandinavian Schools: A Horizon Project Regional Report. Austin, Texas: The New Media Consortium. 
Kungliga biblioteket. (2014). Bibliotek 2014: offentligt finansierade bibliotek.

Retrieved May 25, 2016, from

http://biblioteksstatistik.blogg.kb.se/files/2015/05/Rapport Bibliotek2014.pdf

Linköpings kommuns biblioteksplan 2014-2018. (n.d.). Linköping: Linköpings kommun.

NWEA. (2012). Dylan Wiliam \& The 5 Formative Assessment Strategies to Improve Student Learning. Retrieved May 5, 2016, from

https://www.nwea.org/blog/2012/dylan-wiliam-the-5-formative-assessmentstrategies-to-improve-student-learning/

OECD. (2015). Improving schools in Sweden, an OECD perspective. Retrieved May 5, 2016 from http://www.oecd.org/edu/school/Improving-Schools-in-Sweden.pdf

Pålsson, S. (2016), Skolbibliotekens bidrag till skolans digitalisering. Retrieved May 20, 2016, from http://www.skolverket.se/skolutveckling/resurser-forlarande/skolbibliotek/sa-gor-andra/entillen/digi-1.243597

Skolinspektionen. (n.d.). Skolbibliotek. Retrieved May 20, 2016, from http://www.skolinspektionen.se/skolbibliotek

Skolverket. (2016). Redovisning av uppdraget om att föreslå nationella IT-strategier för skolväsendet. Retrieved May 5, 2016, from http://www.skolverket.se/omskolverket/publikationer/visa-enskildpublikation? xurl =http $\% 3 \mathrm{~A} \% 2 \mathrm{~F} \% 2 \mathrm{Fwww5}$.skolverket.se\%2Fwtpub\%2Fws $\% 2 \mathrm{Fskol}$ bok\%2Fwpubext\%2Ftrycksak\%2FBlob\%2Fpdf3621.pdf\%3Fk\%3D3621

Svensk författningssamling 2010:800 Skollag (2010:800) (n.d.). Retrieved May 20, 2016, from http://www.riksdagen.se/sv/DokumentLagar/Lagar/Svenskforfattningssamling/Skollag-2010800 sfs-2010-800/

Tallvid, H. (2015). 1:1 i klassrummet - analyser av en pedagogisk praktik i förändring. Göteborg: Chalmers Repro Retrieved May 5, 2016, from http://hdl.handle.net/2077/37829 
Timperley, H., Wilson, A., Barrar, H. \& Fung, I. (2007). Teacher professional learning and development. Best Evidence Syntheses Iteration [BES]. New Zealand: Ministry of Education.

Utbildningsdepartementet. (2015). Uppdrag att föreslå nationella it-strategier för skolväsendet. Retrieved May 5, 2016, from

http://www.skolverket.se/polopoly fs/1.240546!/Menu/article/attachment/U201504666-S Nationella it-strategier.pdf

http://skl.se/download/18.492990951464200d71485310/1402989583700/Bok och a ntologi Unos Uno SKL.pdf

\section{Biographical note}

Liselott Drejstam is 39 years old. She has worked as a school librarian since 2002. She has a master degree in library- and information science. She is currently working as a school librarian at Hjulsbroskolan, an F -6 (preschool class-year 6) school in Linköping. Previously, she worked as a secondary school librarian for several years. At Hjulsbroskolan she works closely with teachers to increase better achievement among the pupils and to stimulate reading and increase pupils' media and information literacy. She is very interested in the work to increase pupils' sourcecritical ability, which begins in preschool class. She has lectured at several school library conferences around Sweden. She lives in Linköping with her husband and two children, 6 and 8 years old.

Martina Lundström started her career as a teacher 1998. The subjects she has been teaching are textile craft and Swedish language. Textile craft is a compulsory subject for all children in Sweden. The recent years her main interest has focused on creativity and how to enhance learning with digital tools. 2011 she started working as a Development Manager supervising teachers in how to use ICT in primary and secondary education at the Department of Education in the City of Linköping, Sweden. She believes that technology provides opportunities for everyone to become a producer and that every teacher is obliged to reflect on how to use Internet in teaching. She also thinks that it is a right of democracy to understand our on-line society. Martina is a mother of four boys and lives with her husband in Linköping. 
